\title{
Metaphors in Indonesian Soccer News
}

\author{
Ekaning Krisnawati \\ English Department, Universitas Padjadjaran, Bandung, Indonesia
}

\begin{abstract}
This article discusses a cognitive view on metaphors found in Indonesian soccer news published in two Indonesian newspapers through conceptual metaphor theory, which maps the source domain to the target domain. According to conceptual metaphor theory put forward by Lakoff and Johnson (1980), conceptual metaphors mean the domain of concept $A$ is the domain of concept $B$. The source domain is relatively more concrete than the target domain. Through the mapping of the source and target domains, we can conceptualize metaphors formed by metaphor linguistic expression. Metaphorical inferences can be drawn through neural theory of language which is developed by Lakoff as the neural theory of metaphor. The method employed to identify metaphorical linguistic expressions in the data sources is MIPVU (Metaphor Identification Procedure Vrije Universitet) developed by Steen et al. (2010). The results revealed that metaphorically, the game of soccer perceives goals as gold and crops, and the games themselves are hunting.
\end{abstract}

Index Terms - cognitive linguistics, inferences, metaphor, soccer news, source domain, target domain

\section{INTRODUCTION}

The traditional view on metaphors has emphasized the attempt to create poetic imagination and rhetoric. It is evident, then, that metaphors are the extraordinary imagination of writers, and no one, besides writers, can attempt such an effort due to the crafted skills in creating metaphors. In this view, metaphor is seen as an anomaly or an uncommon, deviant use of language. Philosophers have always regarded metaphors as bound to literature, rhetoric, and the arts since metaphors indicate deviance of humans' clear thoughts (Goatly, 1997).

It is the cognitive view that has changed the traditional assumption toward metaphors. The cognitive view suggests that metaphors exist and are encountered in human's daily life and are conceptualized in human thoughts. We do not readily realize that our utterances may contain metaphors. Stern (2007) stated that conceptual structures are embodied in our experiences, and semantic structures reflect conceptual structures. This recognizes that metaphors exist in our language and thought (Johnson \& Lakoff, 1980; Steen, 2007).

Some studies on metaphors have revealed that metaphor patterns can be identified from corpus (Crisp, et al. 2002); Heywood, et al. (2002) can identify the character of a text or an author's style from the metaphors used in literature. Other studies on metaphor and discourse have emphasized the importance of pressure of coherence (Kövecses, 2009) which has created novel metaphors.

\section{LITERATURE REVIEW}

\section{A. Metaphor and Language}

Discussing metaphor is discussing language usage that refers to something that is not originally refered to or to its literal meaning to point similarity or connect two comparable things (Knowles \& Moon, 2006). Cruse (2000) stated a similar definition which sugests that metaphors are the use of one word or phrase to refer to something different from its literal meaning. Goatly specifically (1997) claimed that

A metaphor occurs when a unit of discourse is used to refer to an object, concept, process, quality, relationship or world to which it does not conventionally refer, or colligates with a unit (s) with which it does not conventionally colligate; and when this unconventional act of reference or colligation is understood on the basis of similarity or analogy involving at least two of the following: the units conventional referent; the unit's actual unconventional referent; the actual referent(s) of the unit's actual colligate(s); the conventional referent of the unit's conventional colligate(s). (p. 105)

What Goatly stated suggested that a discourse unit can be a metaphor if the reference is not the conventional object, concept, process or quality and the difference is understood on the basis of similarity or analogy. To refer to its conventional reference, Goatly (1997) used the term Vehicle, and Topic is the unconventional reference. Another term, Ground, is used to refer to the similarity and/or analogy. An example proposed by Goatly is the following sentence:

(1) The past is a foreign country; they do things differently there.

In the example, the vehicle is a foreign country; the topic is the past and the ground is the fact that things are done differently. Vehicle-term can be a word, a phrase or even a clause or a sentence. The followings are examples of metaphors as proposed by Goalty (1997).

(2) Although Atkinson lost that fight ...

(3) You never know what's around the corner.

(4) Sex is only the liquid centre of the great Newberry Fruit of friendship. (Jilly Cooper) 
(5) Mankind is a club to which we owe a subscription. (G.K. Chesterton).

(6) Too many cooks spoil the broth.

Examples (2) and (3) may not readily be comprehended as metaphors as the phrase lost that fight and around the corner do not instantly indicate similarity or analogy to a specific vehicle. In contrast, examples (4) and (5) denote specifically the liquid centre of the great Newberry Fruit and a club to which we owe a subscription as the vehicles and the topics are sex in (4) and mankind in example (5). The metaphor in the form of a sentence as seen in example (6) is a proverb. This proverb can only be understood when the ground is identified through the similarity or analogy of a specific situation.

Other examples are from Knowles and Moon (2006):

(7) The jewel in Northumbria's ecclesiastical crown is Lindisfarne Priory on Holy Island, built as a monastery in 635 and reached by a tidal causeway.

(8) We used to trash all the teams in Keith Schoolboy League. We had a great squad and no one could touch us.

The words jewel, crown, trash, and touch as used in examples (7) and (8) are used not to refer to their literal meanings. The words jewel and crown in example (7) are used to refer important and valuable things as the literal meanings of jewel and crown indicate. The words trash and touch in example (8) are used to denote success of a team in a game.

\section{B. Metaphor in Cognitive Linguistics}

The work of Lakoff and Johnson (1980) on metaphor from a cognitive view has tremendously inspired many studies. Their study on metaphor has yielded the Conceptual Theory of Metaphor. In their view, metaphor is pervasive in daily human life as can be seen in the following examples:

(9) Your claims are indefensible.

(10) He attacked every weak point in my argument.

(11) I demolished his argument.

(12) I've never won an argument with him.

The four examples (9-12) indicate conceptual metaphor ARGUMENT IS WAR. Arguments are comprehended in our thought as war because the word war is associated with defense, attack, demolish, and won. When we argue with someone, we view the person as an opponent who can attack our position and, therefore, we should defend ours. In an argument, people involved use many strategies to win. This yields the conceptual metaphor ARGUMENT IS WAR.

In the cognitive linguistic view, metaphor is defined as an understanding of one conceptual domain as another conceptual domain (Kövecses, 2010). Metaphor in the cognitive view has two main domains, namely, source domain and target domain. This view proclaims that the conceptual domain of $\mathrm{A}$ is the conceptual of domain $\mathrm{B}$. Kövecses differentiates conceptual metaphor from metaphorical linguistic expressions. The words/phrase indefensible, attacked every weak point in, demolished, and won as used in examples (9-12) are metaphorical linguistic expressions, and the conceptual metaphor built from the expressions is ARGUMENT IS WAR. Conceptual metaphor is used in small capital letters.

Another conceptual metaphor is LOVE IS A JOURNEY. This conceptual metaphor has yielded in the following metaphorical linguistic expressions:

(13) Our relationship has hit a dead-end street.

(14) We may have to go our separate ways.

(15) The relationship isn't going anywhere.

(16) The marriage is on the rocks.

Lakoff (1993) stated that metaphor is an important component in human cognition as it can conceptualize from a less concrete experience to a more concerete experience. In his view, metaphor consists of a source language, a target language, and a set of mappings between the source and the target language. The mapping of LOVE IS A JOURNEY is as follows (Kövecses, 2010).

Source: JOURNEY

the travelers

the vehicle

the journey

the distance covered

the obstacles encountered

decisions about which ways to go

the destinantion(s) of the journey

Target: LOVE

the lovers

the love relationship

events in the relationship

the progress made

the difficulties experienced

choices about what to do

the goal(s) of the relationship

The words dead-end street, separate ways, isn't going anywhere as used in examples (13-15) denote a journey because a journey is associated with the nouns street and way, as well as the verb go. Example (16) is of a particular interest. The phrase on the rocks is an idiom, which means likely to fail soon (Cambridge Advanced Learner's Dictionary, 2003). Although it uses an idiom, the idiom itself contains the word rocks, which may denote an impediment encountered in a journey. The love relationship that is conceptualized as the vehicle encountered an obstacle, in this case, the rocks. Since the rocks hinder the journey, the lovers (the travelers) cannot go on and have to stop. 


\section{Understanding Metaphor}

In understanding metaphors, the Neural Theory of Language (NTL) developed by Lakoff and Feldman (1988) provide the basis of explanation. According to NTL, thought is physical while ideas and the concepts that build ideas are physically computed by the brain structures. Reasoning is the activation of certain neuronal groups in the brain. Feldman (in Lakoff, 2008) argued that meaning is mental simulation, that is, the activation of neurons needed to imagine perceiving or performing the action. Therefore, if we cannot imagine the act of kick a ball, we cannot understand the sentence/utterance of "You are kicking a ball."

NTL suggests that a meaningful node is a node that when activated results in the activation of a whole neural simulation and when inhibited prevents that simulation. For example, when the neuron circuitry of "grasp" is activated, we imagine perceiving or performing grasping. The NTL also states that two neuronal groups can be connected so that each inhibits the activation of the other when there is an active flow of ions of the opposite charge (Lakoff, 2008).

Other features of NTL which denote that psycholinguistics are spreading activation, which is the mechanism of how the brain is shaped 'through experience and best-fit systems' (Lakoff, 2008, p. 23). This suggests that neurons that fire together, wire together. This happens when the activation spreading from A meets the activation spreading from B thus creating a link between A and B and the link gets stronger if the more A and B fire together. Our neural systems are best-fit systems. It means that a linguistic compound makes sense when it fits into a coherent context. Lakoff further illustrates with the following examples:

(17) Bill drank a soda.

(18) Bill drank an elephant.

In order to find out the meanings of the two sentences, we need to build a mental simulation. In (17) we build a frame that Bill is drinking and a frame of soda, as a kind of drink. To understand the meaning of sentence (18), the frame of Bill is drinking is activated and so is the frame of an elephant. The frame of Bill is drinking requires another frame that best fits the coherence - a consumable liquid. The mutual inhibition takes place in our brain, in which a frame of an elephant as an animal is inhibited and another frame of an elephant as a kind of drink is activated. The activation of this new frame is contextually bound because Elephant is a brand of Danish beer.

\section{Inferences}

According to Lakoff (2008) an inference occurs in three different situations. They are:

1. when the activation of a collection of meaningful nodes (the antecedent situation) in a neural circuit leads to the activation of one or more other meaningful nodes (the consequence);

2. when the activation of the antecedent nodes is necessary for the consequence; and,

3. when the inhibition of one or more consequence nodes results in the inhibition of one or more antecedent nodes.

From the three situations, Lakoff (2008) stated that a metaphorical inference occurs when:

1. a metaphorical mapping is activated in a neural circuit;

2. there is an inference in the source domain of the mapping; and,

3. a consequence of the source domain inference is mapped to the target domain, activating a meaningful node.

The example from Lakoff of We're driving in the fast lane on the freeway of love activates the inferences that:

1. the vehicle the travelers are in is going a lot faster than usual;

2. the driving is exciting;

3. it can be dangerous (the travelers can suffer physical harm).

"Freeway of love" then activates the target domain of love and source domain of travel, which yields the activation of the Love is a Journey metaphorical mapping. Based on the inferences of the source domain of travel, the metaphorical inferences are:

1. the relationship the lovers are in is developing a lot faster than usual;

2. the development of the relationship is exciting; and,

3. it can be dangerous (the lovers can suffer physical harm).

\section{METHOD}

This is a qualitative study that is not concerned with the number of sample and population. Rather, the Qualitative Method according to Creswell (2008) is a tool to explore and understand a problem of an individual or group. This method focuses on the explanation and interpretation of the problem discussed which is narrated. This method was selected because it did not attempt to generalize conceptual metaphors found in sport news, but it described metaphors found in sports news. The pieces of sport news were taken from two newspapers published in Indonesia, Kompas and Pikiran Rakyat of June - September 2013 editions.

To determine linguistic metaphor expressions in sport news, the procedure undertaken was the procedures developed by Steen, et al. (2010) called MIPVU (Metaphor Identification Procedure Vrije Universitet). The procedure basically describes the procedure to determine the basic meaning and the contextual meaning of a word. The basic meaning is originated from a dictionary, while the contextual meaning is revealed from the context that bounds the word under consideration. If the basic and the contextual meaning are different, the word has the potential to conceptualize metaphor. 


\section{RESULTS AND DISCUSSION}

There are a variety of metaphorical linguistic expressions in the soccer game news that signal conceptual metaphors. Some expressions are readily recognized to denote soccer while others are general and may be found in other sport news.

\section{GOALS ARE GOLD}

Data 1

Pelatih Spanyol Vicente del Bosque tampaknya akan kembali memercayai duet striker David Villa dan Torres yang mengemas tujuh gol saat melawan Tahiti. (Kompas, 23 June 2013)

Spain coach Vicente del Bosque surely seems to set duo strikers, David Villa and Torres, who packed seven goals in a match against Tahiti.

In Bahasa Indonesia, the phrase mengemas tujuh gol is literally equivalent to pack seven goals. The verb pack mengemas activates a frame of packing and a frame of something covered. In the phrase packed seven goals, the second frame of something covered, is inhibited because it does not fit the system in the brain. The context changes the frame and the other frame of something valuable or important is activated because something valuable or important is usually packed. The following inferences can be drawn:

1. something important or valuable is packed;

2. the package is neat and nice; and,

3. to pack neatly and nicely needs skills.

This activates the target domain of goal and the source domain of gold because for human beings one of the valuable things is gold. Everybody would cognitively come to an agreement that gold is important and valuable. From the analysis, the following metaphorical inferences can be drawn:

1. goals are important and valuable in a soccer game;

2. the game ran well; and,

3. to score goals needs skills and good team work.

Pertinent to data (1), packed seven goals, which was jointly performed by David Villa and Torres, denotes that the players have good skills and along with other players, the team built good team work.

Data 2

"Ini kesempatan besar bagi kami. Kami akan berupaya mendulang banyak gol ke gawang Tahiti," kata pelatih yang menangani Uruguay sejak 2006 tersebut. (Kompas, 23 Juni 2013)

"It is a big opportunity for us. We try to pan many goals to the goal of Tahiti," says the Uruguay coach since 2006.

Data 3

Manchester United pun mendulang poin penuh dalam laga di Stadion Old Trafford, Sabtu (14/9). (Kompas, 15 September 2013)

Manchester United also panned full points in a match at Old Trafford Stadion, Saturday (14/9).

In data (2) the phrase mendulang banyak gol is the literal equivalence of to pan many goals and in data (3) the phrase mendulang poin penuh is the literal equivalence of panned full points. The phrase to pan many goals and panned full points activates a frame of panning and a frame of goals and points. The frame of panning is activated; however, the frame of goals and points is inhibited because the frame of panning is linked to a frame of gold. Through best-fit system in the brain and the context, a new frame of something valuable is activated as gold is characterized as a valuable thing. This frame activates the source domain of gold which yields the following inferences:

1. golds are valuable;

2. to get gold needs effort; and,

3. gold is not easy to get.

The metaphorical mapping of Goals are Gold yields the following inferences:

1. goals are valuable;

2. to score goals needs effort; and,

3. goals are not easy to score.

With the application of conceptual theory of metaphor, the following mapping can be drawn:

Source: GOLD

gold miner

strength of gold miner

effort to obtain

by mining or panning

Target: GOALS

soccer player

good teamwork

effort to obtain by attacking or defending position

in a soccer game

Data 4

Kami memiliki peluang emas melawan Jordania. (Kompas, 8 September 2013)

We have a golden opportunity against Jordan.

A golden opportunity in data (4) is the metaphorical linguistic expression. To understand the metaphorical linguistic expression, our brain activates a frame of gold, not golden, and so it is a frame of opportunity. From the activation of the frame of gold, we can draw some inferences:

1. golden is derived from gold; 
2. golden has the similar entity of gold; and,

3. because gold is valuable, so is golden;

The metaphorical linguistic expression a golden opportunity activates the source domain of gold and the target domain of goals. It results in the conceptual metaphor GOALS ARE GOLD. GOALS ARE GOLD conceptual metaphor produces the following metaphorical inferences:

1. the opportunity is valuable;

2. to get the best result needs good team work;

3. the opportunity is not common; and,

4. the opportunity is to score goals.

\section{GOALS ARE CROPS}

Data 5

Kepercayaan diri Uzbekistan meroket setelah menuai gol tandang yang sangat krusial di markas Jordania dalam laga pertama babak play off Zona Asia Piala Dunia Brasil 2014. (Kompas, 8 September 2013)

Uzbekistan's confidence is shooting up (like a rocket) after reaping crucial guest goals at Jordan's homebase in the first play off match of Asian Zone World Cup 2014.

Data (5) contains two metaphorical linguistic expressions of (1) meroket, which is the literal equivalence of shooting up and (2) menuai gol, which is the equivalence of reaping goals. The verb phrase shooting up activates the frame of confidence. The frame of confidence is inhibited, and to fit the coherence, the frame of a rocket is activated. This yields the inferences:

1. confidence is a substance; and,

2. confidence can rise.

The metaphorical linguistic expression of Uzbekistan's confidence is shooting up is based on a structural conceptual metaphor of MORE IS UP.

Reaping goals is another metaphorical linguistic expression identified from data (5). In order to understand the expression, we build a frame of reaping and a frame of goals. Since the frame of reaping does not perfectly link to the frame of goals, the frame of goals is inhibited and a frame of crop is activated. With this kind of link, we build a mental simulation that goals are crops. In the end, we come up with the following inferences:

1. crops are the result of planting;

2. best crops are from best seeds and treatment; and,

3. crops are valuable for the grower.

Reaping goals activates the target domain of goals and the source domain of crops resulting in the activation of the Goals are Crops metaphorical mapping. The metaphorical inferences are:

1. goals are the purposes of playing soccer games;

2. best goals can be scored through good team work; and

3. goals are valuable for the team.

From the analysis, the following is the mapping of the metaphor GOALS ARE CROPS.

Source: CROPS

result of planting

from good seeds and treatment

valuable for the grower

\section{GAMES ARE HUNTING}

Data 6

Meski telah lolos ke semifinal, mantan pelatih Real Madrid itu tetap membidik kemenangan. (Kompas, 23 Juni 2013)

Although passing through the semifinal, the former Real Madrid coach still shoots at the victory.

Data 7

Tim “Paman Sam” sedang memburu tiket final ketiga secara berurutan setelah tahun 2009 dan 2011. (PR, 24 Juli 2013).

The "Uncle Sam" team is hunting a third final ticket in a row after the years of 2009 and 2011.

The phrases of membidik kemenangan and memburu tiket final are literally equivalent to targets the victory and is hunting a third final ticket. In data (6) the phrase shoot at the victory activates the frame of shooting at and the frame of victory. The frame of victory is inhibited because it does not link to the frame of shooting at. Another frame of target, which best fits the the first frame, is then activated. In data (7) the phrase is hunting a third final ticket activates a frame of hunting and a frame of a third final ticket. The frame of a third final ticket is inhibited because it does not link to the frame of hunting. Through the best-fit system, our brain activates another frame, which is based on the context, of a prey. The frame of prey is activated because it links perfectly with the frame of hunting. From the two sentences in (6) and (7) and the activation of the related frames, the following inferences can be drawn:

1. hunting involves hunters and prey;

2. hunting requires skills; and,

3. the target in hunting is prey. 
These result in the metaphorical mapping of Games are Hunting, which activates the source domain of hunting and the target domain of games. The metaphorical inferences are as follows:

1. soccer games involves two teams;

2. soccer games requires skills (tactics); and

3. the target in soccer games are victory (goals).

With the application of conceptual theory of metaphor, the mapping of the metaphor is illustrated as follows.

Source: HUNTING

hunter

weapon

target: prey

Target: GAMES

soccer player

tactics

target: goal

\section{CONCLUSION}

The metaphorical linguistic expressions found in Indonesian soccer news have revealed some conceptual metaphors that exist in our thought. The main purpose of the game, which is to score goals, has brought about the concept of goals as gold and as crops. Both gold and crops are important for miners and growers in such a way that goals are important for soccer players or soccer teams. With regard to the games of soccer, the games are conceptualized as hunting and the goals serve as the hunted.

\section{REFERENCES}

[1] Creswell, J.W. (2009). Research design. London: Sage Publications Inc.

[2] Crisp, et al. (2002). Metaphor identification and analysis, classification and quantification. Language and Literature 11(1): 5569.

[3] Cruse, A. (2000). Meaning in language. Oxford: Oxford University Press.

[4] Goatly, A. (1997). The language of metaphors. London: Routledge.

[5] Heywood, et al. (2002). Linguistic metaphor identification in two extracts from novels. Language and Literature 11(1): 35-54.

[6] Knowles, $\mathrm{M}$ and Moon, R. (2006). Introducing metaphor. Oxon: Routledge.

[7] Kövecses, Z. (2009). Metaphor, culture and discourse: The Pressure of coherence. In Musolff, A and Zinken J. (eds.) Metaphor and discourse. Hampshire: Palgrave Macmillan.

[8] Kövecses, Z. (2010). Metaphor. New York: Oxford University Press.

[9] Lakoff, G. and Johnson, M. (1980). Metaphors We Live By. Chicago: The University of Chicago Press.

[10] Lakoff, G. (1993). The contemporary theory of metaphor. In Ortony, A (ed.) Metaphor and thought (2nd edition). Cambridge: Cambridge University Press.

[11] Lakoff, G. (2008). The neural theory of metaphor. In Gibbs Jr., RW (ed.) Metaphor and thought. Cambridge: Cambridge University Press.

[12] Lakoff, G. and Johnson, M. (1980). Metaphors we live by. London: The University of Chicago Press.

[13] Nirmala, D. (2010). Komponen makna ungkapan metaforis dalam pileg 2009 dalam wacana surat pembaca di harian Suara Merdeka. Parole 1: 9-24.

[14] Steen, G.J. (2007). Finding metaphor in Grammar and Usage. Amsterdam: John Benjamins Publishing Company.

[15] Steen, G. et al. (2010). A method for linguistic metaphor identification. Amsterdam: John Benjamins Publishing Company.

Ekaning Krisnawati was born in Yogyakarta, Indonesia. She earned her Diploma in Applied Linguistics in Singapore in 2001 and her masters in 2007 from Universitas Padjadjaran, Indonesia majoring in linguistics.

She works at the English Department, Faculty of Arts Universitas Padjadjaran Indonesia. With two of her colleagues from Faculty of Dentistry, Universitas Padjadjaran, she has published a book entitled "English for Dentistry Students" (Bandung, Lembaga Studi Kesehatan Indonesia, 2012). Her research interests are applied linguistics, cognitive linguistics, sociolinguistics, and pragmatics.

Ms. Krisnawati is a member of Indonesian Linguistics Society and Teachers of English as a Foreign Language in Indonesia. 